Published in final edited form as:

Adv Pharmacol. 2019 ; 85: 221-239. doi:10.1016/bs.apha.2019.02.001.

\title{
Biomarkers of Drug-induced Liver Injury
}

\author{
Mitchell R. McGill ${ }^{1,2}$, Hartmut Jaeschke ${ }^{3}$ \\ ${ }^{1}$ Dept. of Environmental and Occupational Health, Fay W. Boozman College of Public Health \\ 2Dept. of Pharmacology and Toxicology, University of Arkansas for Medical Sciences, Little Rock, \\ AR USA \\ ${ }^{3}$ Dept. of Pharmacology, Toxicology, and Therapeutic, University of Kansas Medical Center, \\ Kansas City, KS USA
}

\begin{abstract}
Drug-induced liver injury (DILI) is a major clinical and regulatory challenge. As a result, interest in DILI biomarkers is growing. So far, considerable progress has been made in identification of biomarkers for diagnosis (acetaminophen-cysteine protein adducts), prediction (genetic biomarkers), and prognosis (microRNA-122, high mobility group box 1 protein, keratin-18, glutamate dehydrogenase, mitochondrial DNA). Many of those biomarkers also provide mechanistic insight. The purpose of this chapter is to review major advances in DILI biomarker research over the last decade, and to highlight some of the challenges involved in implementation. Although much work has been done, more liver-specific biomarkers, more DILI-specific biomarkers, and better prognostic biomarkers for survival, are all still needed. Furthermore, more work is needed to define reference intervals and medical decision limits.
\end{abstract}

\section{Keywords}

Hepatotoxicity; Idiosyncratic drug-induced liver injury; Drug regulation; Acetaminophen; Predictive value; Diagnosis; Prognosis

\section{Introduction}

Drug-induced liver injury (DILI) can be a problem at any point in the life cycle of a drug. It is commonly encountered during testing of new drugs, and roughly half with early clinical evidence of hepatotoxicity are terminated before reaching the market (Olson et al., 2000). Post-approval, it is a common reason for black box warnings and other packaging modifications (Issa et al., 2007; Solotke et al., 2018) and for drug withdrawals (Onakpoya et al., 2016). It is also the chief cause of acute liver failure (ALF) in the United States, the United Kingdom, Australia and some European countries (Lee, 2008). Though

Address for Correspondence: Dr. Mitchell R. McGill, Assistant Professor, University of Arkansas for Medical Sciences, $4301 \mathrm{~W}$. Markham St., Slot 820, Little Rock, AR 72205, P. 501-526-6696, mmcgill@uams.edu.

CONFLICT OF INTEREST DISCLOSURE

MRM is a consultant for Acetaminophen Toxicity Diagnostics, Inc., which is developing a diagnostic test for APAP overdose. The authors declare that they have no other conflicts of interest. 
approximately $50 \%$ of drug-induced ALF cases in the US are due to acetaminophen (APAP) overdose (Lee, 2008), many other drugs on the market can also cause hepatotoxicity, including the relatively new class of drugs known as immune checkpoint inhibitors. Clearly, DILI is a serious obstacle in both drug development and patient care.

DILI is often grouped into two classes: 1) intrinsic and 2) idiosyncratic. Intrinsic DILI is hepatotoxicity due to natural properties of a drug or its metabolite(s). It usually involves overdose, and it is highly reproducible. On the other hand, idiosyncratic DILI (IDILI), a subset of the broader category of idiosyncratic adverse drug reactions, occurs at recommended therapeutic doses, and is relatively rare. Some drugs cause IDILI in less than $0.01 \%$ of consumers, though the prevalence of IDILI varies greatly (McGill and Jaeschke, 2018).

Decades after the introduction of alkaline phosphatase and aminotransferases (ALT, AST) as the first biomarkers of liver injury, interest in identification of novel DILI biomarkers has been growing (McGill, 2016). Although current clinical laboratory tests are helpful for detection of liver injury or dysfunction in many cases, they are not useful for diagnosis of etiology or for prognosis (Antoine et al., 2013; Senior, 2014; McGill et al., 2014; Levine et al., 2016; Dear et al., 2018). The US National Institutes of Health and US Food and Drug Administration Biomarker Working Group has defined a biomarker as a "characteristic that is measured as an indicator of normal biological processes, pathogenic processes, or responses to an exposure or intervention" (US FDA, 2016). They further divided biomarkers into seven categories: biomarkers of risk/susceptibility, diagnosis, monitoring, prediction, prognosis, pharmacodynamics, and safety. DILI biomarkers have potential for use in three of those categories: diagnosis, prediction (or risk), and prognosis. Additionally, several biomarkers have been introduced that provide insight into pathophysiological mechanisms, commonly referred to as mechanistic biomarkers. Here, we discuss important recent advances in the DILI biomarker field in each of those categories. Table 1 is a summary of the most promising current DILI biomarkers for these major uses, but we will begin with a discussion of the issue of prevalence, which affects both clinical and regulatory biomarker utility.

\section{The Problem of Low Prevalence in DILI Biomarker Development}

A critical concept in development of serum or plasma biomarkers for DILI is the effect of prevalence on utility. Curiously, although the challenge of low prevalence has been extensively discussed in publications on the subject of genetic biomarkers of IDILI (Alfirovec and Pirmohamed, 2012), it is rarely mentioned with regard to serum DILI biomarkers. It is occasionally proposed that serum or genetic biomarkers could be used to predict IDILI in patients before treatment with a drug known to cause it (Chen et al., 2014). However, the real-world utility of a biomarker depends in part upon the prevalence of the disease or outcome of interest (Fig. 1) (McGill and Jaeschke, 2018), and IDILI is rare. Due to the low prevalence of IDILI among patients taking almost any given IDILI-associated drug, it would be difficult, nearly impossible, to develop a biomarker with sufficient positive predictive value (PPV) to predict it (Fig. 1) (Senior, 2014; McGill and Jaeschke, 2018). Although it has been argued that biomarkers with high negative predictive value (NPV) 
could be used to rule-out risk of IDILI, the pre-test probability is typically $<1 \%$. That is, you can be at least $99 \%$ certain in most cases that IDILI will not occur before administering the drug without the help of a biomarker. So the value added by a high NPV biomarker in that context is questionable.

Nevertheless, there are clear uses of biomarkers in DILI that are not as limited by prevalence. Estimates of the prevalence of all-cause DILI among patients presenting with evidence of acute liver injury range from 10\% to 15\% (Galvin et al., 2015; Björnsson et al., 2016; Breu et al., 2018). Thus, it is theoretically possible to develop a useful biomarker to diagnose DILI in general, though it will have to have high sensitivity and specificity (>90\%) in order to achieve moderately high PPV and NPV (70-80\%). It will also need to be specific for DILI, but not specific for the particular drug that is the cause; as mentioned, the prevalence of DILI due to any single drug would be too low. As we will see, the single exception to the latter is serum APAP-protein adducts to diagnose APAP overdose. Together, those requirements set a very high bar, but not necessarily prohibitively high as long as we understand that the predictive values will be modest. Furthermore, biomarkers may aid prognosis. Approximately $15 \%$ of patients who present early after APAP overdose with normal-to-low ALT values go on to develop hepatotoxicity despite $N$-acetylcysteine treatment (Rumack et al., 1978; 1981; Smilkstein et al., 1991; Antoine et al., 2013). Hence, it is also possible to predict hepatotoxicity in asymptomatic early-presenters with moderateto-high predictive values. Indeed, some biomarkers already show promise for that purpose, and are probably approaching the limits of what is possible. More importantly, biomarkers could be developed for prognosis in drug-induced acute liver failure (DIALF), or ALF in general. ALF and DIALF have very high mortality (Lee, 2012; Reddy et al., 2016; Devarbhavi et al., 2018), so biomarkers with high PPV and NPV for poor outcome could easily be developed (Fig. 1). A biomarker with sensitivity and specificity as low as $80 \%$ could be useful in that context, and considerable research should be focused in that area. Finally, biomarkers could be developed to distinguish between dangerous and innocuous changes in liver function tests, such as the transient ALT elevations that have been reported in patients taking therapeutic doses of APAP (Watkins et al., 2006).

\section{Biomarkers of DILI Diagnosis}

The only major biomarker that has been proposed for diagnosis of DILI so far is proteinderived APAP-cysteine (APAP-CYS). As mentioned above and described in detail elsewhere (Senior, 2014; McGill and Jaeschke, 2018), it would be extremely difficult to develop biomarkers of DILI for most individual drugs. However, APAP overdose accounts for approximately half or more of all DILI cases in many Western countries (Lee, 2008; Galvin et al., 2015; Breu et al., 2018). As a result, it is possible to develop diagnostics specifically for APAP overdose, like APAP-CYS. Such diagnostics could be used to confirm a diagnosis of APAP overdose when multiple etiologies are suspected, or to direct a patient for psychotherapy in cases of APAP overdose with suicidal intent. Three approaches have been used to measure APAP-CYS. The first is an immunoassay using antibodies developed against a conjugate of APAP and $N$-acetylcysteine coupled to keyhole limpet hemocyanin (Roberts et al., 1987). Using an ELISA format, APAP-CYS was measured in liver homogenates and serum from APAP-treated mice (Pumford et al., 1989), and later in serum 
from pediatric APAP overdose patients (James, L.P., Farrar, H.C., Sullivan, J.E., Givens, T.G., et al., 2001). A method based on high pressure liquid chromatography and electrochemical detection (HPLC-EC) improved sensitivity, making it possible to measure protein-derived APAP-CYS in serum in the absence of ALT elevation and even after low doses of APAP (Muldrew et al., 2002; McGill et al., 2013; Heard et al., 2011). More recent methods have been based on HPLC with mass spectrometry (McGill et al., 2011; Cook et al., 2015), with similar results to HPLC-EC. Together, data from studies of protein-derived APAP-CYS in APAP overdose patients have demonstrated that a cutoff of $1 \mathrm{nmol} / \mathrm{mL}$ is sensitive and specific for severe hepatotoxicity (ALT $\geq 1,000 \mathrm{U} / \mathrm{L}$ ) after APAP overdose (James et al., 2009; Heard et al., 2011; Khandelwal et al., 2011; Alonso et al., 2015). More recently, a prospective study across seven sites in the US revealed that a novel point-of-care (POC) lateral flow immunoassay had both PPV and NPV $\searrow 0 \%$ for APAP diagnosis among patients registered in an ALF study (Roberts et al., 2017). Importantly, APAP-protein adducts appear to circulate freely, and therefore are readily detectable by a POC immunoassay (Duan et al., 2019). Overall, available data strongly support the utility of protein-derived APAP-CYS for diagnosis of APAP-induced liver injury.

Although many other biomarkers have been tested for ability to detect DILI, they are not specific for DILI, nor even for the liver in most cases, and therefore cannot diagnose it. For example, circulating keratin 18 (K18) has an area under the receiver operating characteristic (ROC) curve of 0.947 , indicating high sensitivity and specificity for detection of liver injury among patients with a DILI diagnosis (Church and Watkins, 2018). However, K18 is also dramatically increased in plasma from patients with hypoxic hepatitis (Weemhoff et al., 2017), alcohol-associated liver disease (Gonzalez-Quintela et al., 2006; Woolbright et al., 2017), nonalcoholic steatohepatitis (Yilmaz et al., 2007), and other diseases. One exception may be microRNA profiles. There is limited evidence that microRNA profiles can be used to differentiate between causes of acute liver injury (Ward et al., 2014), but that requires further investigation.

\section{Biomarkers of DILI Prediction}

It has been proposed that genetic biomarkers could be developed to predict IDILI, or to manage risk of IDILI, in patients before treatment with an IDILI-associated drug as part of the personalized medicine approach (Urban et al., 2014; Mosedale and Watkins, 2017). Dozens of gene variants have been identified that are associated with susceptibility to DILI (Urban et al., 2014; McGill and Jaeschke, 2018). Many are variants of human leukocyte antigen (HLA) genes (Urban et al., 2014; McGill and Jaeschke, 2018). The only gene variant associated with IDILI for which clinical laboratories currently test is HLA B*5701 in candidates for abacavir treatment (Mallal et al., 2002). However, the utility of HLA B*5701 testing is due to the cumulative prevalence of all immunoallergic reactions to the drug. Approximately $5 \%$ of patients treated with abacavir develop an adverse reaction, but only a fraction of those reactions include liver injury (Hetherington et al., 2001). Other gene variants associated with DILI affect drug metabolizing enzymes (Huang et al., 2003; Daly et al., 2007; Yimer et al., 2012; Markova et al., 2013; Urban et al., 2014), transporters (Haas et al., 2006; Daly et al., 2007), and antioxidant defense systems (Huang et al., 2007; Lucena et al., 2010). 
It is unlikely that many gene variants will be adopted for routine prediction of IDILI among drug treatment candidates. As mentioned, the prevalence of IDILI among users of a given drug is typically very low (Fig. 1). In addition, others have pointed out that nearly all genetic associations with IDILI so far are weak (Mosedale and Watkins, 2017). Still, predictive biomarkers may be useful in some cases. For example, ximelagatran, for which IDILI prevalence is relatively high and there is a fairly robust genetic association with DRB*0701, the probability of toxicity with a positive test result is roughly 20-60\% (Alfirovec and Pirmohamed, 2012). For drugs that have many alternatives or that treat relatively minor conditions, any probability above $10 \%$ or so may be sufficient to compel a clinician not to prescribe it. In the case of a life-saving drug, a clinician may decide to prescribe it despite the risk, but closely monitor liver function tests for evidence of hepatotoxicity.

One application for which genetic biomarkers may be more useful is in the case of patients taking known DILI-causing drug who develop liver test abnormalities. In such a cases, a clinician may wish to determine if the drug is likely to be responsible for the abnormal liver test results. Testing the patient for a gene variant that is strongly associated with DILI for that particular drug may help the clinician to decide if the drug should be discontinued (Mosedale and Watkins, 2017).

\section{Biomarkers of DILI Prognosis}

DILI biomarkers appear to have greater potential for prognosis than for almost any other purpose. Many biomarkers have been tested for prognosis, and a few show promise. In particular, several biomarkers may be useful to determine 1) likelihood of toxicity in earlypresenting APAP overdose patients, and 2) likelihood of mortality in DIALF patients. It should be noted that most of these biomarkers have been primarily tested in APAP overdose patients, due to the greater availability of samples from that population, but we will also discuss evidence from non-APAP DILI studies wherever possible.

One of the most promising prognostic biomarkers is the microRNA miR-122. It has been demonstrated that miR-122 is elevated in circulation in humans after APAP overdose (Starkey Lewis et al., 2011; Ward et al., 2014; Yang et al., 2015; Krauskopf et al., 2015), acute non-APAP DILI (Thulin et al., 2014; Russo et al., 2017), ischemic hepatitis (Weemhoff et al., 2017), and alcohol ingestion (McCrae et al., 2016). It is also somewhat elevated in patients who develop transient ALT elevations after therapeutic doses of APAP or anti-tubercular drugs (Thulin et al., 2014). Most prospective studies so far have demonstrated that admission miR-122 values in early presenters and patients with normal to low-elevated ALT have predictive values in the range of 70-90\% for development of later injury (defined as ALT above a predetermined value) (Antoine et al., 2013; Dear et al., 2018); likely approaching the limit of what is possible based on prevalence (Fig. 1) (McGill and Jaeschke, 2018). The utility of miR-122 to predict mortality after APAP overdose has not been tested, but it has been tested in non-APAP DILI with surprising results (Russo et al., 2017). Values for miR-122 were actually lower in samples from non-survivors compared to survivors, though both groups appeared to have higher values than controls (Russo et al., 2017). It is not yet clear if the difference between survivors and non-survivors is sufficient to determine likelihood of mortality. It should be noted that two major problems with miR-122 
measurement have been described. First, there is controversy surrounding the correct way to measure and normalize miR-122 values (Qi et al., 2012), though novel and rapid point-ofcare methods may help to overcome that issue (Vliegenthart et al., 2017). Second, miR-122 displays high between- and within-subject variability (Church et al., 2018). It has been pointed out that the high biological variation may not matter when applying miR-122 to APAP overdose patients because patients with APAP toxicity have very high values (Church et al., 2018), around two orders of magnitude higher than controls (Starkey Lewis et al., 2011; Yang et al., 2015). But the difference seems to be smaller in non-APAP DILI, which may prohibit its use in that patient population. Indeed, some organizations have already abandoned miR-122 as a serious biomarker for IDILI (Church et al., 2018).

High mobility group box 1 (HMGB1) protein is another promising biomarker of prognosis in DILI. Normally, HMGB 1 is physically associated with DNA, but values for total HMGB1 in circulation are also elevated in DILI patients (Craig et al., 2011; Basta et al., 2015). Despite variation between cohorts, HMGB1 values have performed similarly overall to miR-122 to forecast hepatotoxicity in early-presenting APAP overdose patients (Antoine et al., 2013; Dear et al., 2018). Antoine et al., (2012) also reported evidence that indicates that total HMGB1 values can be used to determine likelihood of mortality after APAP overdose, though the results of that study are currently in question and two other studies found no evidence for higher values in patients with poor outcome after either APAP or non-APAP acute liver injury (Craig et al., 2011; Basta et al., 2015). Overall, HMGB1 values may be useful to predict toxicity in early-presenting APAP overdose patients, but it probably cannot be used to determine mortality. As of yet, no studies have been conducted to test the prognostic value of HMGB1 in non-APAP DILI.

Keratin-18 (K18) is a cytoskeletal protein, but circulating levels are elevated in APAP DILI (Craig et al., 2011; Antoine et al., 2013) and in patients with transient ALT elevations after therapeutic doses of either APAP or anti-tubercular drugs (Thulin et al., 2014). Two forms of K18 have been detected in circulation after DILI (Dear et al., 2018), full-length and caspasecleaved and both forms have potential for prognostic use (Dear et al., 2018). In particular, full-length or total K18 has high sensitivity and specificity for liver injury in earlypresenting APAP overdose patients, though only modest positive predictive value (Dear et al., 2018). Although it was significantly elevated in patients with transaminitis due to antitubercular drugs early after initiation of therapy, ALT was also elevated at that time point so it did not add to the value of traditional clinical laboratory tests (Thulin et al., 2014). However, a more recent study revealed that K18 may be useful to determine likelihood of poor outcomes in patients with both APAP and non-APAP DILI (Dear et al., 2018).

At least two mitochondrial macromolecules are also elevated in DILI. Glutamate dehydrogenase (GLDH) is an enzyme that is elevated in circulation during DILI, as well as other forms of acute liver injury (McGill et al., 2012; 2014; Schomaker et al., 2013). Mitochondrial DNA (mtDNA) is also elevated (McGill et al., 2012; Marques et al., 2012). However, although it was once thought that GLDH and mtDNA may be useful for prognosis in APAP overdose patients, they have poor sensitivity and poor predictive values for prediction of both later injury and mortality (McGill et al., 2014; Dear et al., 2018). 
However, GLDH may be useful to distinguish between liver injury and muscle damage in some cases because GLDH is more liver-specific than ALT or AST (Church et al., 2018).

Finally, liver regeneration biomarkers are in development. Liver regeneration appears to be critical for survival of acute liver injury and ALF. Kayano et al. (1992) reported that proliferating cell nuclear antigen (PCNA) staining is greater in liver tissue from survivors of liver failure than from non-survivors. Furthermore, traditional clinical laboratory markers of liver function that can reflect regeneration and recovery, such as bilirubin and prothrombin time, are associated with mortality (O'Grady et al., 1989; Lee et al., 2005; Church et al., 2018). Unfortunately, those traditional test values increase late in the disease progression, often after injury is complete and treatment becomes more difficult. That late increase limits their utility. Nevertheless, available data indicate that biomarkers of liver regeneration may be useful for prognosis. Indeed, a-fetoprotein (AFP) increases more in survivors of ALF, including APAP-induced ALF, than non-survivors or others with poor outcome (Schmidt and Dalhoff, 2005). However, a problem with AFP is that it does not increase until late in the course of injury. In addition, it is higher in ALF patients compared to non-ALF patients with liver injury (Church et al., 2018) which could make interpretation difficult in a clinical setting. Other regeneration biomarkers that have been proposed include leukocyte cell derived chemotaxin 2 (LECT2) (Sato et al., 2004), butyric acid (Rudnick et al., 2009), and phosphatidic acid (Lutkewitte et al., 2018), but considerably more work is needed to validate them. Research should be focused in development of these regeneration biomarkers because it is clear that markers with high prognostic utility for patient outcome could be developed.

\section{Mechanistic Biomarkers}

Several biomarkers of cell death mechanisms and inflammation have been measured in DILI. HMGB1 in circulation can be a biomarker of oncotic necrosis, inflammation, or both. Cells undergoing apoptosis do not release HMGB1, but necrotic cells and cells undergoing necroptosis do release it (Scaffidi et al., 2002; Tang et al., 2016). HMGB1 acts as a damageassociated molecular pattern (DAMP) and induces inflammation via receptors on macrophages and other inflammatory cells (Andersson et al., 2018). Normally, HMGB1 is sequestered in the nucleus in most cells. However, when inflammation begins, it will be hyperacetylated in inflammatory cells, which causes it to shift out of the nucleus and ultimately targets it for release into the extracellular space (McGill and Jaeschke, 2014; Andersson et al., 2018). Thus, acetylated HMGB1 is considered a biomarker of macrophage activation and inflammation (Bonaldi et al., 2003). Total HMGB1 is elevated in circulation after APAP overdose (Antoine et al., 2013), indicating that the primary mode of cell death in humans with APAP hepatotoxicity is necrosis. Measurements of the caspase-cleaved form of K18 have confirmed that hypothesis. Caspases are zymogens that are activated during apoptosis, among other phenomena (Ramirez and Salveson, 2018). Cleavage of K18 by certain caspases during apoptosis reveals a unique epitope on K18 that can be quantified by immunoassay (Leers et al., 1999). Caspase-cleaved K18 is much lower after APAP overdose in humans than total K18 (Craig et al., 2011; Antoine et al., 2013). Finally, caspase activity can also be measured in circulation as a biomarker of apoptosis (McGill et al., 2012; Lorente et al., 2016), and it is undetectable in APAP overdose patients (McGill et al., 2012).

Together, those data confirm evidence in mice (Gujral et al., 2002), in the metabolically 
competent human hepatocyte cell line HepaRG (McGill et al., 2011) and in primary human hepatocytes (Xie et al., 2014) that oncotic necrosis is the dominant form of cell death in APAP hepatotoxicity and possibly other causes of DILI. Certain cytokines are also increased in circulation in patients with either APAP or non-APAP DILI and also signal inflammation (James, L.P., Farrar, H.C., Darville, T.L., Sullivan, J.E., Given, T.G., et al, 2001; James et al., 2005; Bonkovsky et al., 2018). However, some of these increases of pro-inflammatory cytokines such as IL-1 $\beta$ in APAP overdose patients are minimal (Woolbright and Jaeschke, 2017), which is in agreement with previous animal studies (Williams et al., 2010). Other possible biomarkers of inflammation include osteopontin and macrophage colonystimulating factor receptor (Church et al., 2018), though they require further study for that purpose.

GLDH and mtDNA are considered by many to be biomarkers of mitochondrial damage (McGill and Jaeschke, 2014). Both are localized to the mitochondrial matrix, and are likely only liberated when there is severe mitochondrial damage sufficient to rupture the mitochondrial membranes. It has been demonstrated that both are higher in circulation of mice after APAP overdose than after furosemide overdose (McGill et al., 2012). APAP and furosemide cause a very similar pattern of centrilobular necrosis (McGill et al., 2012), but furosemide does so without affecting mitochondrial function (Wong et al., 2000). Thus, the discovery that GLDH and mtDNA are elevated after APAP overdose in humans indicates that mitochondrial damage occurs in humans during APAP DILI similar to mice (McGill et al., 2012). Consistent with that, there is evidence that long-chain acylcarnitines are biomarkers of mitochondrial dysfunction, and they are also elevated in circulation after APAP overdose in mice and humans (Chen et al., 2009; McGill et al., 2014; Bhattacharyya et al., 2014). Finally, carbamoyl phosphate synthetase-1, another mitochondrial matrix enzyme, is also elevated in APAP hepatotoxicity (Weerasinghe et al., 2014).

Nuclear DNA fragments and nucleosomes may also have mechanistic value. Both nuclear and mitochondrial DNA can act as DAMPs via toll-like receptors and other receptors (Magna and Pisetsky, 2016). Also, in the case of APAP hepatotoxicity, nuclear DNA fragmentation is caused by endonucleases released from damaged mitochondria (Bajt et al., 2006), so nuclear DNA fragments and nucleosomes may also indicate mitochondrial damage in some contexts. Nuclear DNA fragments are elevated in circulation of APAP overdose patients with liver injury (Craig et al., 2011; McGill et al., 2012; 2014).

\section{Conclusions}

Numerous circulating and genetic biomarkers show promise for use in DILI. APAP-CYS is likely useful for diagnosis of APAP overdose. HMGB1 and K18 may have modest prognostic value to determine likelihood of later injury in early-presenting APAP overdose patients, while miR-122 could be more useful for that purpose as well as for early identification of non-APAP DILI. Work to identify predictive biomarkers, like HLA B*5701 for abacavir toxicity, will continue and will hopefully yield great rewards despite the challenge of low prevalence. Finally, insights into pathophysiological mechanisms provided by certain biomarkers, like GLDH and K18, could aid development of new treatments for DILI and ALF. In fact, both the US FDA and the European Medicines Agency have 
expressed support for many of the biomarkers discussed here in the form of letters of support for further research and development.

There are several major areas in which advances are still needed. These include 1) establishment or validation of reference intervals or medical decision limits, respectively, for biomarkers in all categories; 2) identification of liver-specific biomarkers in all categories; 3) identification of DILI-specific, but not drug-specific, biomarkers for general DILI diagnosis; and 4) identification of better biomarkers for prediction of mortality or survival in drug hepatotoxicity and ALF.

\section{ACKNOWLEDGEMENTS}

Work in the authors' laboratories was supported by a Pinnacle Research Award from the American Association for the Study of Liver Diseases (AASLD) Foundation, the National Institutes of Health grant R01 DK102142, and the National Institute of General Medical Sciences (P20 GM103549 and P30 GM118247) from the National Institutes of Health.

\section{NON-STANDARD ABBREVIATIONS}

$\begin{array}{ll}\text { ALF } & \text { Acute liver failure } \\ \text { AFP } & \text { a-fetoprotein } \\ \text { APAP } & \text { Acetaminophen } \\ \text { APAP-CYS } & \text { Acetaminophen-cysteine } \\ \text { ALT } & \text { Alanine aminotransferase } \\ \text { AST } & \text { Aspartate aminotransferase } \\ \text { DIALF } & \text { Drug-induced acute liver failure } \\ \text { DILI } & \text { Drug-induced liver injury } \\ \text { GLDH } & \text { Glutamate dehydrogenase } \\ \text { HMGB1 } & \text { High mobility group box 1 protein } \\ \text { IDILI } & \text { Idiosyncratic drug-induced liver injury } \\ \text { K18 } & \text { Keratin-18 } \\ \text { mtDNA } & \text { Mitochondrial DNA } \\ \text { PCNA } & \text { Proliferating cell nuclear antigen } \\ \text { PPV } & \text { Positive predictive value } \\ \text { NPV } & \text { Negative predictive value }\end{array}$




\section{References}

Alfirevic A, Pirmohamed M (2012) Predictive genetic testing for drug-induced liver injury: considerations of clinical utility. Clin Pharmacol Ther, 92, 376-380. [PubMed: 22850601]

Alonso EM, James LP, Zhang S, Squires RH; Pediatric Acute Liver Failure Study Group. (2015) Acetaminophen Adducts Detected in Serum of Pediatric Patients With Acute Liver Failure. J Pediatr Gastroenterol Nutr, 61, 102-107. [PubMed: 25859823]

Andersson U, Yang H, Harris H (2018) High-mobility group box 1 protein (HMGB1) operates as an alarmin outside as well as inside cells. Semin Immunol, doi: 10.1016/j.smim.2018.02.011. [Epub ahead of print]

Antoine DJ, Dear JW, Lewis PS, Platt V, Coyle J, Masson M, et al. (2013) Mechanistic biomarkers provide early and sensitive detection of acetaminophen-induced acute liver injury at first presentation to hospital. Hepatology, 58, 777-787. [PubMed: 23390034]

Antoine DJ, Jenkins RE, Dear JW, Williams DP, McGill MR, Sharpe MR, et al. (2012) Molecular forms of HMGB1 and keratin-18 as mechanistic biomarkers for mode of cell death and prognosis during clinical acetaminophen hepatotoxicity. J Hepatol, 56, 1070-1079. [PubMed: 22266604]

Bajt ML, Cover C, Lemasters JJ, Jaeschke H (2006) Nuclear translocation of endonuclease G and apoptosis-inducing factor during acetaminophen-induced liver cell injury. Toxicol Sci, 94, 217-225. [PubMed: 16896059]

Basta G, Del Turco S, Navarra T, Lee WM; Acute Liver Failure Study Group. (2015) Circulating levels of soluble receptor for advanced glycation end products and ligands of the receptor for advanced glycation end products in patients with acute liver failure. Liver Transpl, 21, 847-854. [PubMed: 25825217]

Bhattacharyya S, Yan K., Pence L, Simpson PM, Gill P., Letzig LG, et al. (2014) Targeted liquid chromatography-mass spectrometry analysis of serum acylcarnitines in acetaminophen toxicity in children. Biomark Med, 8, 147-159. [PubMed: 24521011]

Bonaldi T, Talamo F, Scaffidi P, Ferrera D, Porto A, Bachi A, et al. (2003) Monocytic cells hyperacetylate chromatin protein HMGB1 to redirect it towards secretion. EMBO J 22, 5551-5560. [PubMed: 14532127]

Bonkovsky HL, Barnhart HX, Foureau DM, Steuerwald N, Lee WM, Gu J, et al. Cytokine profiles in acute liver injury-Results from the US Drug-Induced Liver Injury Network (DILIN) and the Acute Liver Failure Study Group. PLoS One, 13:e0206389.

Björnsson HK, Olafsson S, Bermann OM, Björnsson S (2016) A prospective study on the causes of notably raised alanine aminotransferase (ALT). Scand J Gastroenterol, 51, 594-600. [PubMed: 26653080]

Breu AC, Patwardhan VR, Nayor J, Ringwala JN, Devore ZG, Ganatra RB, et al. (2018) A Multicenter Study Into Causes of Severe Acute Liver Injury. Clin Gastroenterol Hepatol, doi: 10.1016/ j.cgh.2018.08.016 [Epub ahead of print]

Chen M, Borlak J, Tong W (2014) Predicting idiosyncratic drug-induced liver injury: some recent advances. Expert Rev Gastroenterol Hepatol, 8, 721-723. [PubMed: 24857265]

Chen C, Krausz KW, Shah YM, Idle JR, Gonzalez FJ (2009) Serum metabolomics reveals irreversible inhibition of fatty acid beta-oxidation through the suppression of PPARalpha activation as a contributing mechanism of acetaminophen-induced hepatotoxicity. Chem Res Toxicol, 22, 699707. [PubMed: 19256530]

Church RJ, Watkins PB (2018) Serum biomarkers of drug-induced liver injury: current status and future directions. J Dig Dis, doi: 10.1111/1751-2980.12684 [Epub ahead of print]

Church RJ, Kullak-Ublick GA, Aubrecht J, Bonkovsky HK, Chalasani N, Fontana RJ, et al. (2018) Candidate biomarkers for the diagnosis and prognosis of drug-induced liver injury: An international collaborative effort. Hepatology, doi: 10.1002/hep.29802 [Epub ahead of print]

Cook SF, King AD, Chang Y, Murray GJ, Norris HR, Dart RC, et al. (2015) Quantification of a biomarker of acetaminophen protein adducts in human serum by high-performance liquid chromatography-electrospray ionization-tandem mass spectrometry: clinical and animal model applications. J Chromatogr B Analyt Technol Biomed Life Sci, 985, 131-141. 
Craig DG, Lee P, Pryde EA, Masterton GS, Hayes PC, Simpson KJ (2011) Circulating apoptotic and necrotic cell death markers in patients with acute liver injury. Liver Int, 31, 1127-1136. [PubMed: 21745283]

Daly AK, Aithal GP, Leathart JB, Swainsbury RA, Dang TS, Day CP (2007) Genetic susceptibility to diclofenac-induced hepatotoxicity: contribution of UGT2B7, CYP2C8, and ABCC2 genotypes. Gastroenterology, 132, 272-281. [PubMed: 17241877]

Dear JW, Clarke JI, Francis B, Allen L, Wraught J, Shen J, et al. (2018) Risk stratification after paracetamol overdose using mechanistic biomarkers: results from two prospective cohort studies. Lancet Gastroenterol Hepatol, 3, 104-113. [PubMed: 29146439]

Devarbhavi H, Patil M, Reddy VV, Singh R, Joseph T, Ganga D (2018) Drug-induced acute liver failure in children and adults: Results of a single-centre study of 128 patients. Liver Int, 38, 13221329. [PubMed: 29222960]

Duan L, Ramachandran A, Akakpo JY, Weemhoff JL, Curry SC, Jaeschke H (2019) Role of extracellular vesicles in release of protein adducts after acetaminophen-induced liver injury in mice and humans. Toxicol Lett 301, 125-132. [PubMed: 30447259]

Galvin Z, McDonaugh A, Ryan J, Stewart S (2015) Blood alanine aminotransferase levels >1,000 IU/l - causes and outcomes. Clin Med (Lond), 15, 244-247. [PubMed: 26031973]

Gonzalez-Quintela A, García J, Campos J, Perez LF, Alende MR, Otero E, et al. (2006) Serum cytokeratins in alcoholic liver disease: contrasting levels of cytokeratin-18 and cytokeratin-19. Alcohol, 38, 45-49. [PubMed: 16762691]

Gujral JS, Knight TR, Farhood A, Bajt ML, Jaeschke H (2003) Mode of cell death after acetaminophen overdose in mice: apoptosis or oncotic necrosis? Toxicol Sci, 67, 322-328.

Haas DW, Bartlett JA, Andersen JW, Sanne I, Wilkinson GR, Hinkle J, et al. (2006) Pharmacogenetics of nevirapine-associated hepatotoxicity: an Adult AIDS Clinical Trials Group collaboration. Clin Infect Dis, 43, 783-786. [PubMed: 16912957]

Heard KJ, Green JL, James LP, Judge BS, Zolot L, Rhyee S, Dart RC (2011) Acetaminophen-cysteine adducts during therapeutic dosing and following overdose. BMC Gastroenterol, 11:20. [PubMed: 21401949]

Hetherington S, McGuirk S, Powell G, Cutrell A, Naderer O, Spreen B, et al. (2001) Hypersensitivity reactions during therapy with the nucleoside reverse transcriptase inhibitor abacavir. Clin Ther, 23, 1603-1614. [PubMed: 11726000]

Huang YS, Chern HD, Su WJ, Wu JC, Chang SC, Chiang CH, et al. (2003) Cytochrome P450 2E1 genotype and the susceptibility to antituberculosis drug-induced hepatitis. Hepatology, 37, 924930. [PubMed: 12668988]

Huang YS, Su WJ, Huang YH, Chen CY, Chang FY, Lin HC, Lee SD (2007) Genetic polymorphisms of manganese superoxide dismutase, $\mathrm{NAD}(\mathrm{P}) \mathrm{H}$ :quinone oxidoreductase, glutathione $\mathrm{S}$-transferase M1 and T1, and the susceptibility to drug-induced liver injury. J Hepatol, 47, 128-134. [PubMed: 17400324]

Issa AM, Phillips KA, Van Bebber S, Nidamarthy HG, Lasser KE, Haas JS, et al. (2007) Drug withdrawals in the United States: a systematic review of the evidence and analysis of trends. Curr Drug Saf, 2, 177-185. [PubMed: 18690965]

James LP, Farrar HC, Darville TL, Sullivan JE, Given TG, Kearns GL, et al. (2001) Elevation of serum interleukin 8 levels in acetaminophen overdose in children and adolescents. Clin Pharmacol Ther, 70, 280-286. [PubMed: 11557916]

James LP, Farrar HC, Sullivan JE, Givens TG, Kearns GL, Wasserman GS et al. (2001) Measurement of acetaminophen-protein adducts in children and adolescents with acetaminophen overdoses. J Clin Pharmacol, 41, 846-851. [PubMed: 11504272]

James LP, Letzig L, Simpson PM, Capparelli E, Roberts DW, Hinson JA, et al. (2009) Pharmacokinetics of acetaminophen-protein adducts in adults with acetaminophen overdose and acute liver failure. Drug Metab Dispos, 37, 1779-1784. [PubMed: 19439490]

James LP, Simpson PM, Farrar HC, Kearns GL, Wasserman GS, Blumer JL, et al. (2005) Cytokines and toxicity in acetaminophen overdose. J Clin Pharmacol, 45, 1165-1171. [PubMed: 16172181] 
Kayano K, Yasunaga M, Kubota M, Takenaka K, Mori K, Yamashita A, et al. (1992) Detection of proliferating hepatocytes by immunohistochemical staining for proliferating cell nuclear antigen (PCNA) in patients with acute hepatic failure. Liver, 12, 132-136. [PubMed: 1380112]

Khandelwal N, James LP, Sanders C, Larson AM, Lee WM; Acute Liver Failure Study Group. (2011) Unrecognized acetaminophen toxicity as a cause of indeterminate acute liver failure. Hepatology, 53, 567-576. [PubMed: 21274877]

Krauskopf J, Caiment F, Claessen SM, Johnson KJ, Warner RL, Schomarker SJ, et al. (2015) Application of high-throughput sequencing to circulating microRNAs reveals novel biomarkers for drug-induced liver injury. Toxicol Sci, 143, 268-276. [PubMed: 25359176]

Lee WM (2008) Etiologies of acute liver failure. Semin Liver Dis, 28, 142-152. [PubMed: 18452114]

Lee WM (2012) Recent developments in acute liver failure. Best Pract Res Clin Gastroenterol, 26, 316. [PubMed: 22482521]

Lee WS (2005) Etiology, outcome and prognostic indicators of childhood fulminant hepatic failure in the United Kingdom. J Pediatr Gastroenterol Nutr, 40, 575-581. [PubMed: 15861019]

Leers MP, Kölgen W, Björklund V, Bergman T, Tribbick G, Persson B, et al. (1999) Immunocytochemical detection and mapping of a cytokeratin 18 neo-epitope exposed during early apoptosis. J Pathol, 187, 567-572. [PubMed: 10398123]

Levine M, O'Connor AD, Padilla-Jones A, Gerkin RD (2016) Comparison of prothrombin time and aspartate aminotransferase in predicting hepatotoxicity after acetaminophen overdose. J Med Toxicol, 12, 100-106. [PubMed: 26341088]

Lorente L, Martín MM, Ferreres J, Solé-Violán J, Labarta L, Díaz C, et al. (2016) Serum caspase 3 levels are associated with early mortality in severe septic patients. J Crit Care, 34, 103-106. [PubMed: 27288619]

Lucena MI, García-Martín E, Andrade RJ, Martínez C, Stephens C, Ruiz JD, et al. (2010) Mitochondrial superoxide dismutase and glutathione peroxidase in idiosyncratic drug-induced liver injury. Hepatology, 52, 303-312. [PubMed: 20578157]

Lutkewitte AJ, Schweitzer GG, Kennon-McGill S, Clemens MM, James LP, Jaeschke H, et al. (2018) Lipin deactivation after acetaminophen overdose causes phosphatidic acid accumulation in liver and plasma in mice and humans and enhances liver regeneration. Food Chem Toxicol, 115, 273283. [PubMed: 29534981]

Magna M, Pisetsky DS (2016) The Alarmin Properties of DNA and DNA-associated Nuclear Proteins. Clin Ther, 38, 1029-1041. [PubMed: 27021604]

Mallal S, Nolan D, Witt C, Masel G, Martin AM, Moore C, et al. (2002) Association between presence of HLA-B*5701, HLA-DR7, and HLA-DQ3 and hypersensitivity to HIV-1 reverse-transcriptase inhibitor abacavir. Lancet, 359, 727-732. [PubMed: 11888582]

Markova SM, De Marco T, Bendjilali N, Kobashigawa EA, Mefford J, Sodhi J, et al. (2013) Association of CYP2C9*2 with bosentan-induced liver injury. Clin Pharmacol Ther, 94, 678-686. [PubMed: 23863877]

Marques PE, Amaral SS, Pires DA, Nogueira LL, Soriani FM, Lima BH, et al. (2012) Chemokines and mitochondrial products activate neutrophils to amplify organ injury during mouse acute liver failure. Hepatology, 56, 1971-1982. [PubMed: 22532075]

McCrae JC, Sharkey N, Webb DJ, Vliegenthart AD, Dear JW (2016) Ethanol consumption produces a small increase in circulating miR-122 in healthy individuals. Clin Toxicol (Phila), 54, 53-55. [PubMed: 26574140]

McGill MR (2016) The past and present of serum aminotransferases and the future of liver injury biomarkers. EXCLI J, 15, 817-828. [PubMed: 28337112]

McGill MR, Jaeschke H (2014) Mechanistic biomarkers in acetaminophen-induced hepatotoxicity and acute liver failure: from preclinical models to patients. Expert Opin Drug Metab Toxicol, 10, 1005-1017. [PubMed: 24836926]

McGill MR, Jaeschke H (2018) Biomarkers of drug-induced liver injury: progress and utility in research, medicine, and regulation. Expert Rev Mol Diagn, 18, 797-807. [PubMed: 30080986]

McGill MR, Lebosky M, Norris HR, Slawson MH, Bajt ML, Xie T, et al. (2013) Plasma and liver acetaminophen-protein adduct levels in mice after acetaminophen treatment: dose-response, 
mechanisms, and clinical implications. Toxicol Appl Pharmacol, 269, 240-249. [PubMed: 23571099]

McGill MR, Li F, Sharpe MR, Williams CD, Curry SC, Ma X, Jaeschke H (2014) Circulating acylcarnitines as biomarkers of mitochondrial dysfunction after acetaminophen overdose in mice and humans. Arch Toxicol, 88, 391-401. [PubMed: 23979652]

McGill MR, Sharpe MR, Williams CD, Taha M, Curry SC, Jaeschke H (2012) The mechanism underlying acetaminophen-induced hepatotoxicity in humans and mice involves mitochondrial damage and nuclear DNA fragmentation. J Clin Invest, 122, 1574-1583. [PubMed: 22378043]

McGill MR, Staggs VS, Sharpe MR, Lee WM, Jaeschke H; Acute Liver Failure Study Group. (2014) Serum mitochondrial biomarkers and damage-associated molecular patterns are higher in acetaminophen overdose patients with poor outcome. Hepatology, 60, 1336-1345. [PubMed: 24923598]

McGill MR, Yan HM, Ramachandran A, Murray GJ, Rollins DE, Jaeschke H (2011) HepaRG cells: a human model to study mechanisms of acetaminophen hepatotoxicity. Hepatology, 53, 974-982. [PubMed: 21319200]

Mosedale M, Watkins PB (2017) Drug-induced liver injury: Advances in mechanistic understanding that will inform risk management. Clin Pharmacol Ther, 101, 469-480. [PubMed: 27861792]

Muldrew KL, James LP, Coop L, McCullough SS, Hendrickson HP, Hinson JA, Mayeux PR (2002) Determination of acetaminophen-protein adducts in mouse liver and serum and human serum after hepatotoxic doses of acetaminophen using high-performance liquid chromatography with electrochemical detection. Drug Metab Dispos, 30, 446-451. [PubMed: 11901099]

O'Grady JG, Alexander GJ, Hayllar KM, Williams R (1989) Early indicators of prognosis in fulminant hepatic failure. Gastroenterology, 97, 439-445. [PubMed: 2490426]

Olson H, Betton G, Robinson D, Thomas K, Monro A, Kolaja G, et al. (2000) Concordance of the toxicity of pharmaceuticals in humans and in animals. Regul Toxicol Pharmacol, 32, 56-67. [PubMed: 11029269]

Onakpoya IJ, Heneghan CJ, Aronson JK (2016) Post-marketing withdrawal of 462 medicinal products because of adverse drug reactions: a systematic review of the world literature. BMC Med, 14, 10. [PubMed: 26843061]

Pumford NR, Hinson JA, Potter DW, Rowland KL, Benson RW, Roberts DW (1989) Immunochemical quantitation of 3-(cystein-S-yl)acetaminophen adducts in serum and liver proteins of acetaminophen-treated mice. J Pharmacol Exp Ther, 248, 190-196. [PubMed: 2913271]

Qi R, Weiland M, Gao XH, Zhou L, Mi QS (2012) Identification of endogenous normalizers for serum microRNAs by microarray profiling: U6 small nuclear RNA is not a reliable normalizer. Hepatology, 55, 1640-1642.

Ramirez MLG, Salveson GS (2018) A primer on caspase mechanisms. Semin Cell Dev Biol, 82, 7985. [PubMed: 29329946]

Reddy KR, Ellerbe C, Schilsky M, Stravitz RT, Fontana RJ, Durkalsi V, et al. Determinants of outcome among patients with acute liver failure listed for liver transplantation in the United States. Liver Transpl, 22, 505-515. [PubMed: 26421889]

Roberts DW, Lee WM, Hinson JA, Bai S, Swearingen CJ, Stravitz RT, et al. (2017) An Immunoassay to Rapidly Measure Acetaminophen Protein Adducts Accurately Identifies Patients With Acute Liver Injury or Failure. Clin Gastroenterol Hepatol, 15, 555-562. [PubMed: 27641661]

Roberts DW, Pumford NR, Potter DW, Benson RW, Hinson JA (1987) A sensitive immunochemical assay for acetaminophen-protein adducts. JPharmacol Exp Ther, 241, 527-533. [PubMed: 3572810]

Rudnick DA, Dietzen DJ, Turmelle YP, Shepherd R, Zhang S, Belle SH, et al. (2009) Serum alphaNH-butyric acid may predict spontaneous survival in pediatric acute liver failure. Pediatr Transplant, 13, 223-230. [PubMed: 18643912]

Rumack BH, Peterson RG (1978) Acetaminophen overdose: incidence, diagnosis, and management in 416 patients. Pediatrics, 62, 898-903. [PubMed: 724342]

Rumack BH, Peterson RC, Koch GG, Amara IA (1981) Acetaminophen overdose. 662 cases with evaluation of oral acetylcysteine treatment. Arch Intern Med, 141, 380-385. [PubMed: 7469629] 
Russo MW, Steuerwald N, Norton HJ, Anderson WE, Foureau D, Chalasani N, et al. (2017) Profiles of miRNAs in serum in severe acute drug induced liver injury and their prognostic significance. Liver Int, 37, 757-764. [PubMed: 27860186]

Sato Y, Watanabe H, Kameyama H, Kobayashi T, Yamamoto S, Takeishi T, et al. (2004) Serum LECT2 level as a prognostic indicator in acute liver failure. Transplant Proc, 36, 2359-2361. [PubMed: 15561249]

Scaffidi P, Mistelli T, Bianchi ME (2002) Release of chromatin protein HMGB1 by necrotic cells triggers inflammation. Nature, 418, 191-195. [PubMed: 12110890]

Schmidt LE, Dalhoff K (2005) Alpha-fetoprotein is a predictor of outcome in acetaminophen-induced liver injury. Hepatology, 41, 26-31. [PubMed: 15690478]

Schomarker S, Warner R, Bock J, Johnson K, Potter D, Van Winkle J, Aubrecht J (2013) Assessment of emerging biomarkers of liver injury in human subjects. Toxicol Sci, 132, 276-283. [PubMed: 23339181]

Senior JR (2014) New biomarkers for drug-induced liver injury: are they really better? What do they diagnose? Liver Int, 34, 325-327. [PubMed: 25839081]

Smilkstein MJ, Bronstein AC, Linden C, Augenstein WL, Kulig KW, Rumack BH (1991) Acetaminophen overdose: a 48-hour intravenous $\mathrm{N}$-acetylcysteine treatment protocol. Ann Emerg Med, 20, 1058-1063. [PubMed: 1928874]

Starkey Lewis PJ, Dear J, Platt V, Simpson KJ, Craig DG, Antoine DJ, et al. (2011) Circulating microRNAs as potential markers of human drug-induced liver injury. Hepatology, 54, 1767-1776. [PubMed: 22045675]

Solotke MT, Dhruva SS, Downing NS, Shah ND, Ross JS (2018) New and incremental FDA black box warnings from 2008 to 2015. Expert Opin Drug Saf, 17, 117-123. [PubMed: 29215916]

Tang Y, Zhao X, Antoine DJ, Xiao X, Wang H, Andersson U, et al. (2016) Regulation of Posttranslational Modifications of HMGB1 During Immune Responses. Antioxid Redox Signal, 24, 620-634. [PubMed: 26715031]

Thulin P, Nordahl G, Gry M, Yimer G, Aklilu E, Makonnen E, et al. (2014) Keratin-18 and microRNA-122 complement alanine aminotransferase as novel safety biomarkers for drug-induced liver injury in two human cohorts. Liver Int, 34, 367-378. [PubMed: 24118944]

Urban TJ, Daly AK, Aithal GP (2014) Genetic basis of drug-induced liver injury: present and future. Semin Liver Dis, 34, 123-133. [PubMed: 24879978]

United States Food and Drug Administration. (2016) BEST (Biomarkers, EndpointS, and other Tools) Resource Glossary. Retrieved from https://www.ncbi.nlm.nih.gov/books/NBK326791/

Vliegenthart ADB, Berends C, Potter CMJ, Kersaudy-Kerhoas M, Dear JW (2017) MicroRNA-122 can be measured in capillary blood which facilitates point-of-care testing for drug-induced liver injury. Br J Clin Pharmacol, 83, 2027-2033. [PubMed: 28257154]

Ward J, Kanchagar C, Veksler-Lublinsky I, Lee RC, McGill MR, Jaeschke H et al. (2014) Circulating microRNA profiles in human patients with acetaminophen hepatotoxicity or ischemic hepatitis. Proc Natl Acad Sci U.S.A, 111, 12169-12174. [PubMed: 25092309]

Watkins PB, Kaplowitz N, Slattery JT, Colonese CR, Colucci SV, Stewart PW, Harris SC (2006) Aminotransferase elevations in healthy adults receiving 4 grams of acetaminophen daily: a randomized controlled trial. JAMA, 296, 87-93. [PubMed: 16820551]

Weemhoff JL, Woolbright BL, Jenkins RE, McGill MR, Sharpe MR, Olson JC, et al. (2017) Plasma biomarkers to study mechanisms of liver injury in patients with hypoxic hepatitis. Liver Int, 37, 377-384. [PubMed: 27429052]

Weerasinghe SV, Jang YJ, Fontana RJ, Omary MB (2014) Carbamoyl phosphate synthetase-1 is a rapid turnover biomarker in mouse and human acute liver injury. Am J Physiol Gastrointest Liver Physiol, 307, G355-364. [PubMed: 24924744]

Williams CD, Farhood A, Jaeschke H (2010) Role of caspase-1 and interleukin-1beta in acetaminophen-induced hepatic inflammation and liver injury. Toxicol Appl Pharmacol 247, 169_ 78. [PubMed: 20637792]

Wong SG, Card JW, Racz WJ (2000) The role of mitochondrial injury in bromobenzene and furosemide induced hepatotoxicity. Toxicol Lett, 116, 171-181. [PubMed: 10996478] 
Woolbright BL, Bridges BW, Dunn W, Olson JC, Weinman SA, Jaeschke H (2017) Cell Death and Prognosis of Mortality in Alcoholic Hepatitis Patients Using Plasma Keratin-18. Gene Expr, 17, 301-312. [PubMed: 28770701]

Woolbright BL, Jaeschke H (2017) Role of the inflammasome in acetaminophen-induced liver injury and acute liver failure. J Hepatol 66, 836-848. [PubMed: 27913221]

Xie Y, McGill MR, Dorko K, Kumer SC, Schmitt TM, Forster J, Jaeschke H (2014) Mechanisms of acetaminophen-induced cell death in primary human hepatocytes. Toxicol Appl Pharmacol, 279, 266-274. [PubMed: 24905542]

Yang X, Salminen WF, Shi Q, Greenhaw J, Gill PS, Bhattacharyya S, et al., (2015) Potential of extracellular microRNAs as biomarkers of acetaminophen toxicity in children. Toxicol Appl Pharmacol, 284, 180-187. [PubMed: 25708609]

Yilmaz Y, Dolar E, Ulukaya E, Akgoz S, Keskin M, Kiyici M, et al. (2007) Soluble forms of extracellular cytokeratin 18 may differentiate simple steatosis from nonalcoholic steatohepatitis. World J Gastroenterol, 13, 837-844. [PubMed: 17352011]

Yimer G, Amogne W, Habtewold A, Makonnen E, Ueda N, Suda A, et al. (2012) High plasma efavirenz level and CYP2B6*6 are associated with efavirenz-based HAART-induced liver injury in the treatment of naïve HIV patients from Ethiopia: a prospective cohort study. Pharmacogenomics J, 12, 499-506. [PubMed: 21862974] 


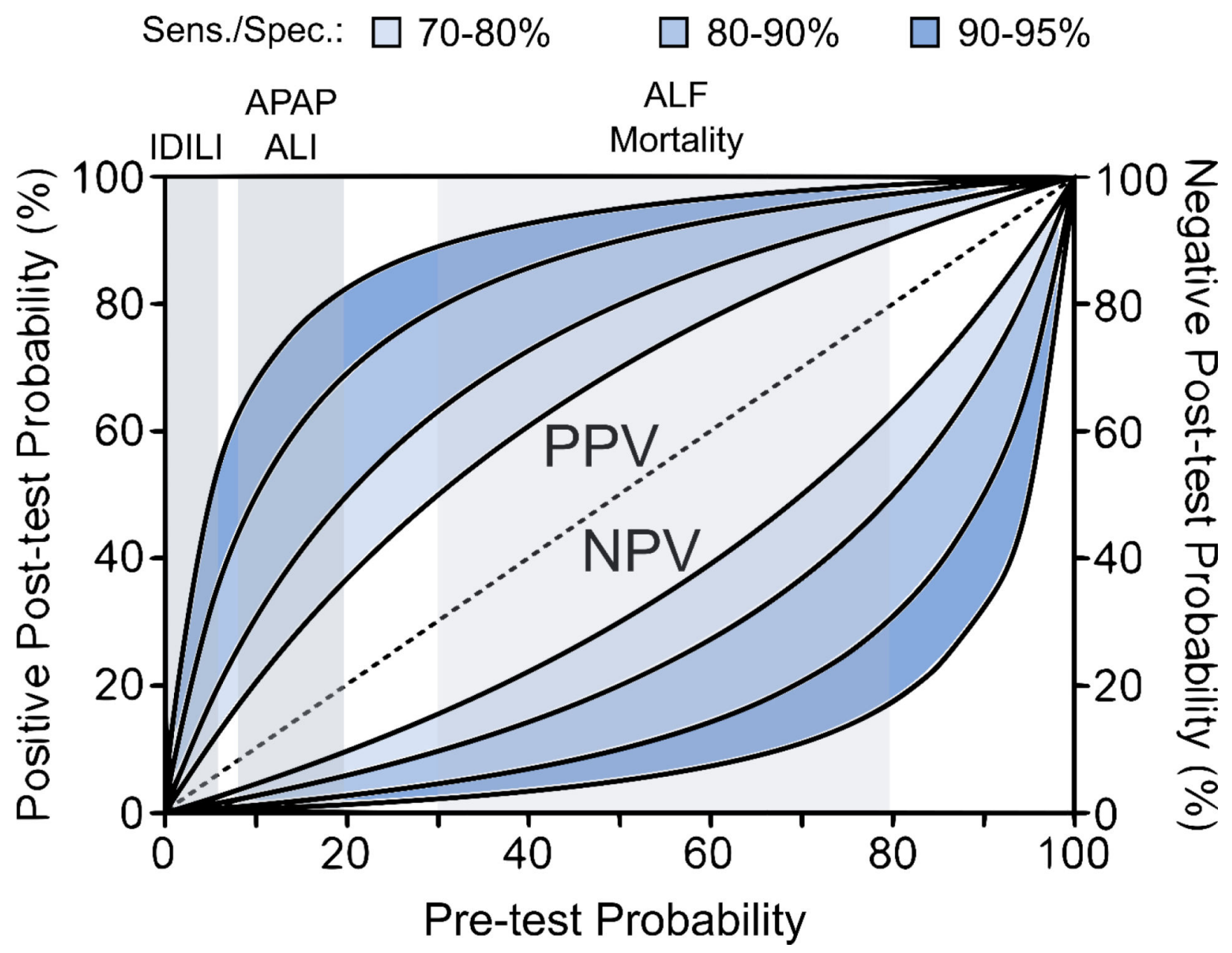

Figure 1. Relationship between prevalence and predictive values.

Positive post-test probability (left upper portion), a surrogate of PPV when pre-test probability or prevalence is estimated, increases with increasing prevalence, while negative post-test probability (right lower portion), a surrogate for negative predictive value (NPV), decreases. Blue-shaded areas show different levels sensitivity and specificity. For the different levels, both sensitivity and specificity were set at either $70 \%, 80 \%, 90 \%$, or $95 \%$. Vertical, grey-shaded areas show the approximate ranges of prevalence for idiosyncratic drug-induced liver injury (IDILI) among users of a given IDILI-associated drug, for acute liver injury (ALI) among early-presenting acetaminophen (APAP) overdose patients, and for mortality among acute liver failure (ALF) patients. 
Table 1.

\begin{tabular}{|c|c|}
\hline \multicolumn{2}{|r|}{ Most Promising DILI Biomarkers } \\
\hline$\overline{3}$ & Diagnostic biomarkers \\
\hline 윽 & Protein-derived APAP-CYS \\
\hline d & Predictive biomarkers \\
\hline$\overline{\bar{c}}$ & Genetic associations (e.g. HLA B*5701) \\
\hline$\subseteq$ & Prognostic biomarkers \\
\hline চ் & miR-122 \\
\hline & HMGB1 \\
\hline & K18 \\
\hline & Mechanistic biomarkers \\
\hline & HMGB1 \\
\hline & K18 \\
\hline$D$ & GLDH \\
\hline & mtDNA \\
\hline & Nuclear DNA fragments \\
\hline
\end{tabular}

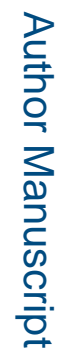

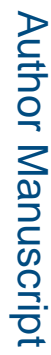

Adv Pharmacol. Author manuscript; available in PMC 2020 July 11. 